\title{
Probing into Economic Development Studies in the Post-COVID Era
}

\author{
VASILII EROKHIN \\ School of Economics and Management, Harbin Engineering University, \\ 145, Nantong Str., Harbin 150001, China.

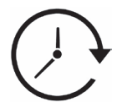 \\ Article History \\ Published by: 21 June 2021 \\ The global economy is now under extremely severe pressure from a great variety of political, economic, \\ social, environmental, and public health challenges. The COVID-19 pandemic has significantly disrupted \\ economic activity in most countries of the world. The scale of the problem was so significant that the world \\ economy was unprepared for it. Restrictive measures taken by the authorities of different countries led to \\ a partial or even complete shutdown of production, a sharp decline in the service sector. These changes \\ will largely determine the specifics of economic and social development in the nearest years. Such global \\ cataclysms usually re-shape long-established trends, turning them into irreversible shifts.
}

The pandemic has aggravated the recurrent problems of poverty and income inequality between countries, food insecurity and hunger, unemployment and social disorders that have resulted in the exacerbation of political, economic, and trade tensions between countries. The China-USA trade war, the Russia-West retaliatory sanctions and tensions, the China-India border conflict, the elections-related social tensions in the USA, the Black Lives Matter global movement, anti-lockdown riots in Europe - all these problems flared up in 2020. The COVID-19 outbreak has unravelled aggregating problems. For several years now, global trade systems have been increasingly distorted by unfair and inefficient policies in many countries, creating both winners and losers. Some states, primarily leading food producers, introduce export bans in an effort to decrease domestic food prices and create food reserves. Some countries impose import bans in retaliation of the international sanctions (Russia since 2014). There are trade tensions (US-China, the most demonstrative example), in which tariffs become a tool of economic and even political pressure. The new highly volatile global environment calls for a comprehensive analysis of multidimensional contributing factors to be able to get the economy back on track of stable and sustainable development at the earliest.

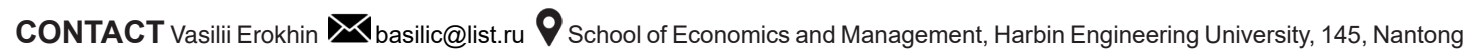
Str., Harbin 150001, China.

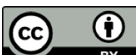

(C) 2021 The Author(s). Published by Enviro Research Publishers.

This is an $\partial$ Open Access article licensed under a Creative Commons license: Attribution 4.0 International (CC-BY).

Doi: http://dx.doi.org/10.12944/JBSFM.02.01.02 
The pandemic will be curbed, but the protectionism outbreak's effects would have a much longer-lasting impact on production, international supply chains, and economic development worldwide.

In these extreme conditions, it is necessary to explore the theme of economic development in the era of instability by studying how the basic concepts and theories of economic development and growth could be adapted to the "new normal". An emphasis should be made on studying developing and poor countries that are particularly vulnerable to economic, social, and political distortions. Before the COVID-19 outbreak, over two billion most impoverished people in the world spent up to $70 \%$ of their disposable income on food (FAO et al., 2020). Food shortages and economic crises would increase this figure. Many developing economies rely on imports. In a situation of disrupting supply, such dependence tremendously threatens the security of those nations.

Eradicating poverty and reducing inequality are among the core United Nations' Sustainable Development Goals (SDGs) to be reached by 2030 (United Nations, 2021). They are systematically linked with each other as well as with the remaining SDGs, and thus they formulate the vision of sustainable development of the world over the next decade. Unfortunately, despite the international community's efforts to combat poverty and inequality, both parameters have been on the rise recently. Therefore, there is a strong need to find a workable (and appropriate in these new conditions) resolution to poverty problems to avoid a global crisis. The new reality of poverty and inequality issues should be addressed by studying global income disparities and possible ways to bridge gaps between poorer and wealthier countries (and people within countries) by promoting innovations, technologies, human capital development, agrarian systems, and social entrepreneurship.

The particular focus should be made on the new challenges to sustainable development brought by the growth of global environmental and public health problems, such as climate change, deterioration of air, water, land, and other resources, reduction of biodiversity, and loss of many natural ecosystems. Population growth leads to the fact that the amount of natural resources per capita decreases every year, despite scientific and technological progress in the main resource sectors. Many countries are concerned about ensuring resource security, especially energy security, and reducing their dependence on resource-supplying countries. This leads to increased global competition for resources, especially energy, and energy issues are becoming central links of the new policy. There should be developed the approaches to the new interpretation of sustainable development concepts in light of the post-pandemic revival of global economic activity.

In the course of the pandemic-caused economic decline, governments seek to secure their markets by protecting domestic producers (WTO, 2020). In some cases, trade restrictions they impose may result in the improvement of self-sufficiency, but they challenge adequate, diverse, and balanced supplies. Global trade has encountered one of the most vigorous pressure tests ever due to the outbreak of the COVID-2019. Supply chains have been disrupted by lockdowns, quarantine checks, and other prevention measures. As more and more countries worldwide have imposed trade restrictions since the onset of the pandemic, such ultra-protectionist actions have created extreme volatilities in the market, provoking shortages and resulting in supply crises. Future studiesshould address the effects of tariff escalations, administrative restrictions, and other forms of trade protectionism on global supply chains. Ultimately, scholars should probe into many of the choices that link national, regional, and global policies extensively with the provision of sustainable supply, welfare, and economic growth through international cooperation in the new era of the post-COVID global economy.

\section{References}

1. Food and Agriculture Organization of the United Nations, International Fund for Agricultural Development, United Nations Children's Fund, World Food Programme, World Health Organization. 
EROKHIN, Journal of Business Strategy, Finance and Management, Vol. 02(1 \& 2) 04-06 (2021)

(2020). The State ofFood Security and Nutrition in the World 2020. Transforming Food Systems for Affordable Healthy Diets. Rome: FAO.

2. United Nations. (2021). Sustainable Development Goals. Retrieved June 21, 2021, fromhttps://www. un.org/sustainabledevelopment/sustainable-development-goals/.

3. World Trade Organization. (2020). The COVID-19 Pandemic and Trade-Related Developments in LDCs. Retrieved June 21, 2021, fromhttps://www.wto.org/english/tratop_e/covid19_e/ldcs_report_e. pdf 